\title{
Trend analysis of catching fish Decapterus sp. in the Muncar Coastal Fisheries Port, Banyuwangi, Indonesia
}

\author{
Devi Purwinda ${ }^{1}$, Hany Handajani ${ }^{1}$, Anis Zubaidah ${ }^{1 *}$ \\ ${ }^{1}$ Aquaculture Department, Faculty of Agriculture and Animal Science, University of Muhammadiyah \\ Malang, Indonesia. \\ *aniszubaidah@umm.ac.id \\ ${ }^{*}$ Corresponding author
}

\begin{tabular}{|c|c|}
\hline ARTICLE INFO & ABSTRACT \\
\hline $\begin{array}{l}\text { Keywords: } \\
\text { CPUE } \\
\text { Flying fish } \\
\text { Purse seine } \\
\text { Catch production }\end{array}$ & $\begin{array}{l}\text { Small pelagic fish resources in the Java Sea, especially Banyuwangi, are } \\
\text { dominated by catches of Decapterus sp, which are mostly landed at the } \\
\text { UPT of the Coastal Fisheries Port Muncar. This study aimed to provide } \\
\text { information on CPUE trends (Catch Per Unit Effort) and the seasonality } \\
\text { of flying fish in the Coastal Fisheries Port Muncar as an effort to } \\
\text { encourage effective and sustainable in using of fishery resources. The } \\
\text { method used in this study was a survey. The research data was } \\
\text { obtained through secondary data including time series of the production } \\
\text { of catches of flying fish, and trip data of purse seine, payang and bagan } \\
\text { from } 2015 \text { to } 2019 \text { collected by Coastal Fisheries Port Muncar. The } \\
\text { analysis used the CPUE analysis by comparing catches to capture } \\
\text { attempts. The results showed, from } 2015 \text { to } 2019 \text {, the highest CPUE of } \\
\text { flying fish occurred in } 2019 \text {, amounting to } 13365.5 \mathrm{~kg} / \text { trip, while the } \\
\text { lowest CPUE occurred in } 2016 \text { amounted to } 1050.6 \mathrm{~kg} / \text { trip. The trend } \\
\text { of CPUE flying fish from } 2015 \text { to } 2019 \text { experienced a fluctuating increase } \\
\text { with an average of } 7327.5 \mathrm{~kg} / \text { trip. A good season for flying fishing } \\
\text { occurs from May to December, and shares a peak in December, while } \\
\text { famine occurs in January. }\end{array}$ \\
\hline \multirow[t]{2}{*}{ How to cite: } & $\begin{array}{l}\text { Purwinda D, Handajani H, Zubaidah A. 2020. Trend analysis of catching } \\
\text { fish (Decapterus sp.) in the Muncar Coastal Fisheries Port Muncar, } \\
\text { Banyuwangi, Indonesia. IJOTA. 3(2): 70-77. } \\
\text { DOI: https://doi.org/10.22219/ijota.v3i2.12939 }\end{array}$ \\
\hline & $\begin{array}{l}\text { Copyright (@) 2020, Purwinda et al. } \\
\text { This is an open access article under the CC-BY-SA license }\end{array}$ \\
\hline
\end{tabular}

\section{Introduction}

Banyuwangi is the most eastern district of East Java province, which has great fishery potential because the area is directly bordered by the Bali Strait and the Indian Ocean (DPKB, 2010). Banyuwangi coast has several fishing ports, one of which is the Coastal Fishing Port, Muncar. It is one of the places where most of the fisheries in Banyuwangi are landed and dominated by flying fish (Wijaya, 2002). Decapterus sp. is one of the fisheries resources that play a role in the economic 
sector in fisheries in the Java Sea with a production level of $60 \%$ of the total catch of other small pelagic fish, so that flying fish is sought after and is the main target of catches (Aziz et al, 2000). Flyfish have a size of about $15 \mathrm{~cm}$ to $25 \mathrm{~cm}$ with the characteristic presence of small fins (finlets) behind the dorsal and anal fins, as well as the presence of thick cold scales (lateral scute) in the lateral line (Nontji, 2002; Ditjen Fisheries, 1998).

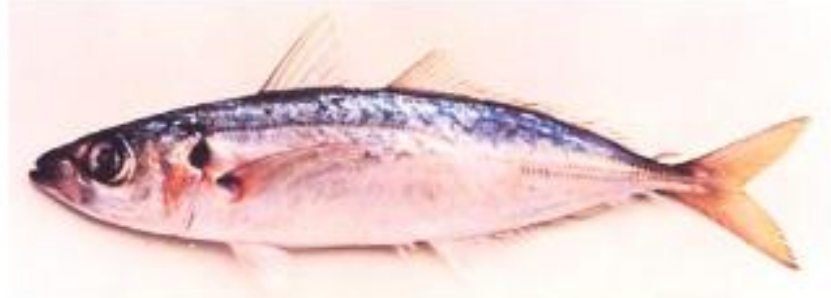

Figure 1. Flying Fish (Decapterus sp.)

Small-sized of flying fish is generally caught using a net, while large ones are caught with a circular net (purse seine), and medium-sized fish are caught with a parasol. Research from Wijayanto (2016) showed the Coastal Fisheries Port Muncar is more interested in using purse seine than other equipments. The catches using purse seine are bigger, but the magnitude of the catches of the floating fish is uncertain, or there is a fluctuation in the cathing of the flying fish due to the uncertain fishing season, and the estimated famine season cannot be determined in Banyuwangi Sea.

Based on these problems, it is necessary to research so that the need for payang fish resources continues to be fulfilled so that it needs an effective purse seine fishing operation, one of which is through information on the CPUE trends in flying fish and estimation of the pattern of fishing seasons landed at PPP Muncar. Estimation of fly fishing patterns will provide information to determine the operational time of flying fishing, thus minimizing the risk of loss.

\section{Material and methods}

This research employed survey approach. The collected data is secondary data which was calculated statistically from 2015 to 2019 of fishery activities in the Coastal Fishing Port, Muncar, and supporting data such as journals, and related literature that supported this research. The obtained statistical data were the value of production and average catches of flying fish, annual and monthly production data per type of fishing gear (purse seine, paying, and net), and catches pereffort capture (CPUE). The data that had been obtained was then processed using Microsoft Excel software. The seasonal pattern of catching fishes was determined by the time series analysis approach for the preparation of the fishing season index (IMP) (Haluan, 2001). Catches per capture attempt could be calculated using the following formula provided by (Gulland, 1893; Mahmud, 2015).

$$
\text { CPUEi }=\frac{C i}{F i}
$$

CPUEi : catch per attempt in the year ( $\mathrm{kg} / \mathrm{trip})$

$\mathrm{Ci} \quad$ : catches per year $(\mathrm{kg})$

$\mathrm{Fi} \quad$ : attempt to catch per year (trip) 


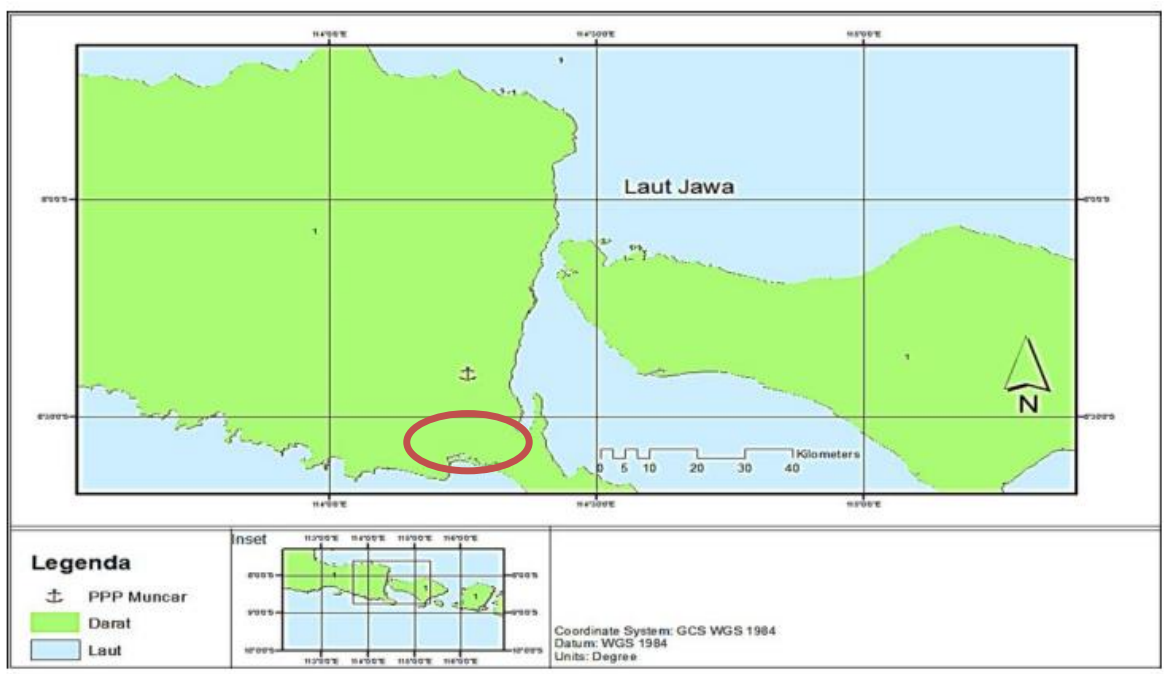

Figure 2. Research Location Map

Source: Imron, 2017

\section{Results and Discussion}

\subsection{Amount of production and average fly fishing}

The development of the number of fly fish production from 2015 to 2019 fluctuated. It decreased from 2015 to 2017 and there was a significant jump up to 2019. The data could be seen in Figure 3:

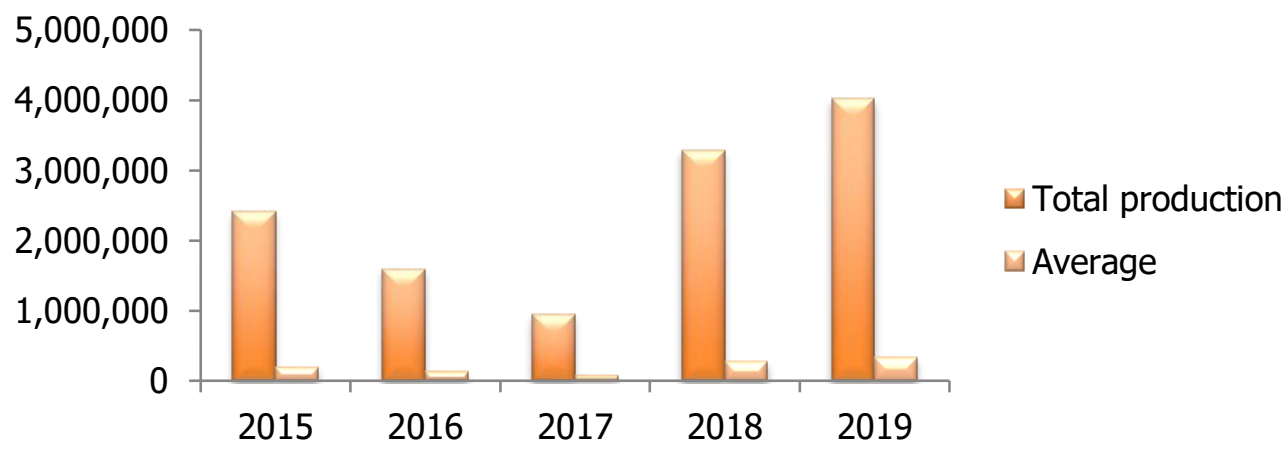

Figure 3. Total Production and Average of Catching Flying Fish from 2015 to 2019

Based on Figure 3, it could be seen that the data experienced fluctuations in flying fish production. From 2015 to 2017, the catch of the flying fish has decreased dramatically with the lowest amount of production occurring in 2017, which was $949318 \mathrm{~kg}$ (with an average of 79110 $\mathrm{kg}$ ), and there was a significant increase until 2019 with a total production by $4021635 \mathrm{~kg}$ (with an average by $335114 \mathrm{~kg}$ ).

The terrible season or bad weather caused a decrease in the number of fish catches in the Bali Strait fish from 2015 to 2017 because the small-sized of vessels could not reach fishing areas, and go to sea. The cause a decrease in fishing yield is the influence of changes in environmental conditions, such as wind, salinity, temperature, weather, and season. Other factors that cause a decline in fishing yields are over-fishing efforts in the Java Sea, including in the western Java Sea and East Java Sea (Prihartini et al, 2007; Perdana et al, 2012). 


\subsection{Catching gear of Flying Fish at Muncar Coastal Fishing Port}

The coastal fishing port, Muncar is one of the places where most of the flying fish are landed in Banyuwangi. The catch of flying fish in Muncar used many fishing tools with different productivity. In this study, the researchers chose to examine 3 fishing gear namely, purse seine, payang, and bagan as fishing gear that had high, medium, and low effectiveness. A purse seine was usually used to catch large-sized of flying fish, for medium-sized fish caught with paying, while small-sized flaying fish were caught with a chart.

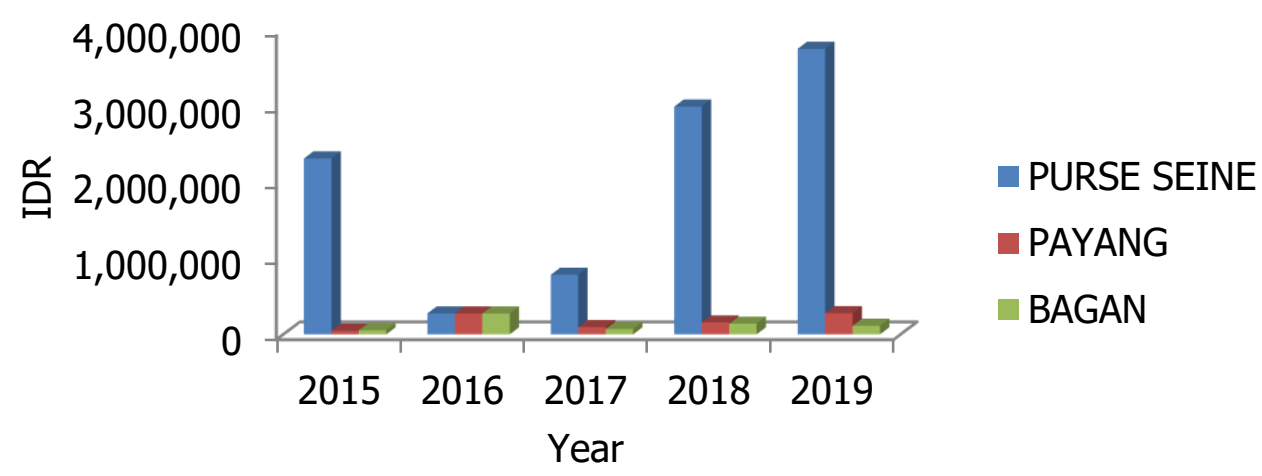

Figure 4. Catching of flying fish from 2015 to 2019

Figure 4 shows a very significant catch from 2015 to 2019 . Fishing gear that is very influential for the results of flying fish is purse seine. This fishing gear had a very significant effect compared to the payang and bagan fishing gear. The highest catch yield using purse seine fishing gear was IDR 3755746 in 2019, and the lowest in 2016 was IDR 274 200. Paying fishing gear with the highest fishing yields was IDR 278639 in 2019, and the lowest in 2015 was IDR 47 645. The catch results using bagan fishing gear was amounted IDR 274200 in 2016 and the lowest in 2015 was amounted IDR 53945.

The above data proves the results of each fishing gear are not the same and the volume of fish income is also different for each fishing gear, so it can be concluded that the use of fishing gear has a significant effect on the catches of floating fish. From 2015 to 2019, the purse seine fishing gear increased very dramatically and significantly because the purse seine had high fishing effectiveness, so it could catch fish in large numbers. Another factor that influences the magnitude of purse seine productivity is the number of fishing gear in Banyuwangi is widely available (DPKB, 2010) so that the catch of fishermen using this tool is also large.

Flying fish could be caught long year because its salinity tolerance is not much different from the salinity of tropical and subtropical waters (Almuas, 2005). Payang is a type of traditional tool and has not changed much but is still a productive tool, while the fishing gear of bagan uses lights and nets, the bagan can only be used at night and the capacity is not large enough (Widjojo, 1966).

\subsection{Catching production of flying fish in the coastal fishing port, Muncar}

Catch fishing production in the Muncar, Banyuwangi using purse seine showed very significant fluctuations. Fishing data could be seen in Figure 5. In 2019, the data showed that the production of flying fish revealed a higher increase by $3755746 \mathrm{~kg}$. Meanwhile, the lowest fishing production in 2016 was $274200 \mathrm{~kg}$. 


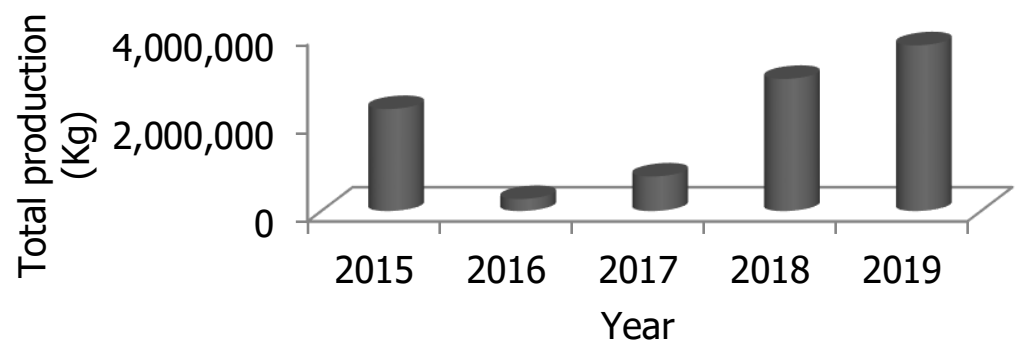

Figure 5. Annual production of catches of flying fish

Figure 5 shows the annual production of catches of flying fish with the use of purse seine and the results are quite significant. In 2019, the data above showed that the production of flying fish showed a higher increase by $3755746 \mathrm{~kg}$, while the lowest fishing production in 2016 was 274200 $\mathrm{kg}$.

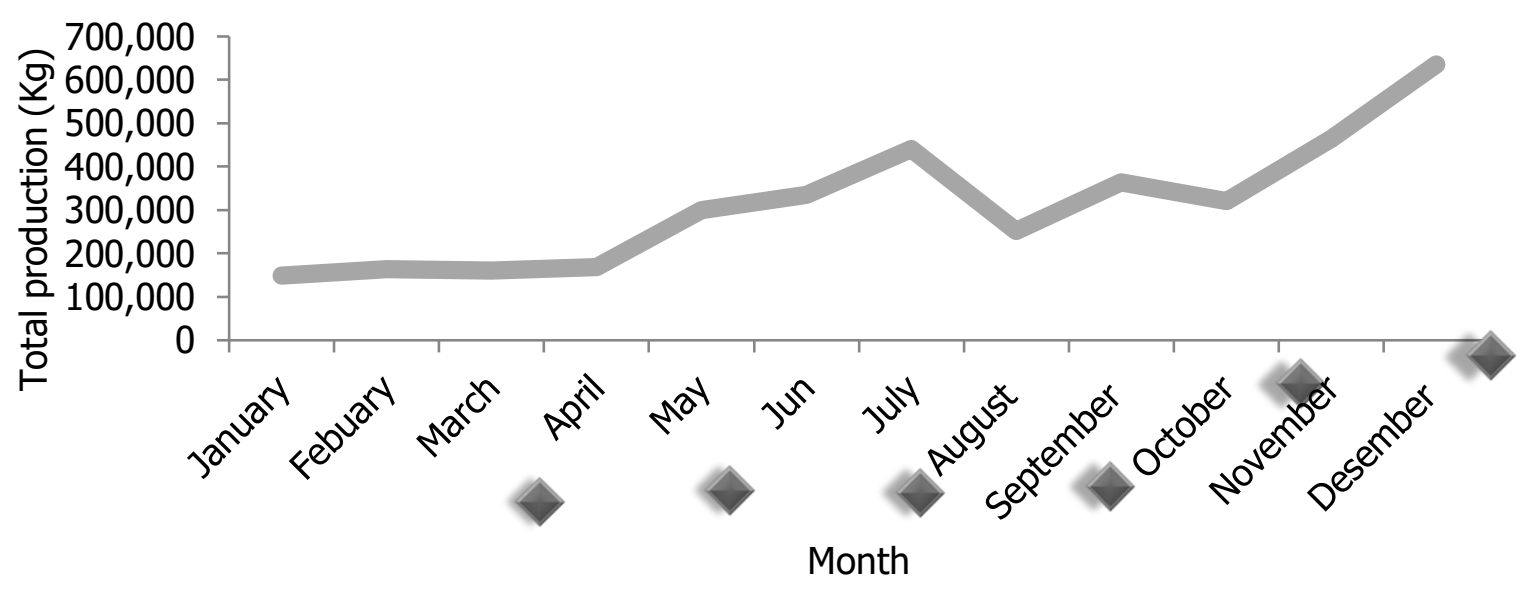

Figure 6. Monthly Catch Production of Flying Fish in 2019

Catch fishing production based on Figure 6 shows significant data. On december showed the highest production of flying fish by $635448 \mathrm{~kg}$, while the lowest was in January by $149504 \mathrm{~kg}$. The ups and downs in fishing production were influenced by seasonal factors or environmental conditions. The peak season for catching flying fish occured in July because in July the season has begun to enter the fishing season.

In the east season, there is a dry season in Indonesian which results in high water sanitation so that the flying fish groups are more in the catching area than in the western season (beginning of the rainy season). According to Genisa (1998), in July to December (east season), flying fish migrate through the Java Sea, and in December to January (west season). During the eastern season, there are many fish in the Java Sea when the season is relatively calm and the fish are large so that the fishermen can get more catch (Astuti, 2008).

\subsection{Efforts to catch flying fish in Muncar}

In the effort to catch of flying fish, there are 3 fishing gears used for catching flying fish. The fishing gear that is used is the purse seine, payang, and bagan. Data could be seen in Figure 7. 


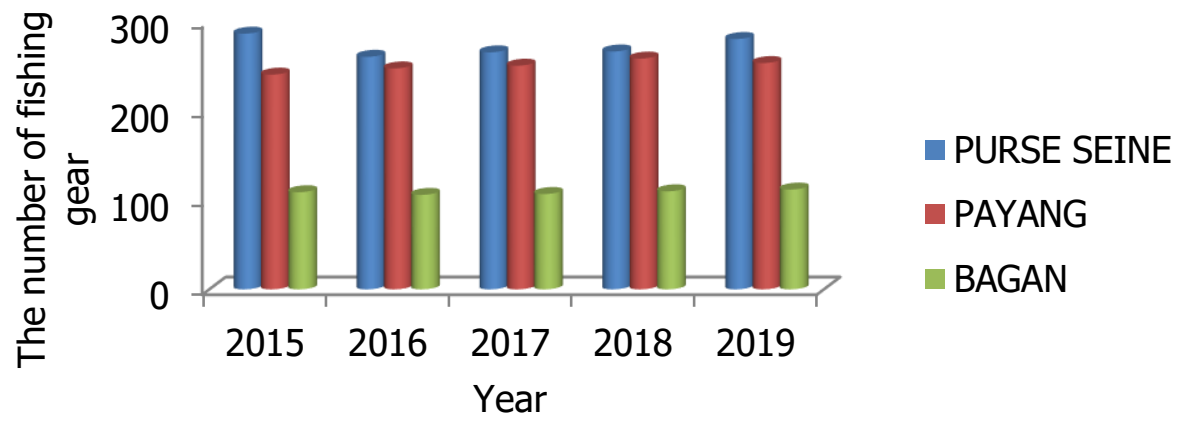

Figure 7. Efforts to catch flying fish from 2015 to 2019

Efforts to catch of flying fish from 2015 to 2019 showed that the results of fishing using purse seine were more dominant compared to the use of paying and bagan fishing equipment. Catching using purse seine fishing gear resulted in a high fishing yield by 281 units, while in the payang fishing gear was 254 units and in the bagan fishing gear was 112 units. Futhermore, purse seine fishing gear on the income of flying fish was very influential.

The catch using purse seine fishing gear was indeed quite high and continued to increase every year. It is equipped with a ring and also a wrinkle rope / dirty rope and nets that originally do not have a pocket will form at the end of the capture. In purse seine fishing gear also showed several factors, namely the search for fish groups, the encirclement of fish groups, and the operation of the net (Inoue, 1961). It is also different from the paying and baan fishing gear because payang is a traditional net and the catch has not changed because according to fishermen this tool is still productive, and the bagan is a fishing gear using nets and lights, and the fishing is only done at night (Widjojo, 1966).

\subsection{Catch-catching efforts (CPUE) of flying fish}

Catch-catching efforts (CPUE) of Flying Fish in the catch (purse seine, paying, and bagan) has different functions, and ways to get the results of flying fish. The capacity that is obtained for each fishing gear is also different. In the calculation of CPUE itself to see how the rate of capture and effort in a capture. From the results obtained with CPUE, there were catches and efforts that is protrayed in Table 1.

Table 1. Catching Production, Catching Efforts and Flying Fish CPUE

\begin{tabular}{|c|c|c|c|c|c|c|c|c|c|}
\hline \multirow[b]{2}{*}{ Year } & \multicolumn{3}{|c|}{ Purse seine } & \multicolumn{3}{|c|}{ Paying } & \multicolumn{3}{|c|}{ Bagan } \\
\hline & $\begin{array}{c}\text { Catch } \\
(\mathrm{Kg})\end{array}$ & $\begin{array}{l}\text { Effort } \\
\text { (Unit) }\end{array}$ & $\begin{array}{c}\text { CPUE } \\
\text { (Kg/Unit) }\end{array}$ & $\begin{array}{c}\text { Catch } \\
(\mathrm{Kg})\end{array}$ & $\begin{array}{l}\text { Effort } \\
\text { (Unit) }\end{array}$ & $\begin{array}{c}\text { CPUE } \\
\text { (Kg/Unit) }\end{array}$ & $\begin{array}{c}\text { Catch } \\
(\mathrm{Kg})\end{array}$ & $\begin{array}{l}\text { Effort } \\
\text { (Unit) }\end{array}$ & $\begin{array}{c}\text { CPUE } \\
\text { (Kg/Unit) }\end{array}$ \\
\hline 2015 & 2312667 & 287 & 8058.1 & 47.645 & 241 & 198 & 52945 & 109 & 485.7 \\
\hline 2016 & 274200 & 261 & 1050.6 & 274.200 & 248 & 1.106 & 274200 & 106 & 2586.8 \\
\hline 2017 & 783665 & 266 & 2946.1 & 95.495 & 251 & 380 & 70030 & 107 & 654.5 \\
\hline 2018 & 2995007 & 267 & 11217.3 & 156.285 & 259 & 603 & 140275 & 110 & 1275.2 \\
\hline 2019 & 3755746 & 281 & 13365.6 & 278.639 & 254 & 1.097 & 112051 & 112 & 1000.5 \\
\hline Jumlah & $\begin{array}{c}10121 \\
285\end{array}$ & 1.362 & 36638 & 852264 & 1253 & 3384 & 649501 & 544 & 6003 \\
\hline Average & & & 7327.5 & & & 677 & & & 1200.5 \\
\hline $\mathrm{FPI}$ & & & 1 & & & 0.1 & & & 0.2 \\
\hline
\end{tabular}


The development of flying fish production from 2015 to 2019 has fluctuated. The decline of flying fish production occurred in 2016 and 2017 then increased until 2019. The decrease in CPUE might also be caused by the increase of fishing grounds distant due to changes in weather, salinity, wind, temperature, population and resource of fish communities. According to Avrionesti (2018), pelagic fish are very sensitive to environmental changes, they live at depths of around $40 \mathrm{~m}$ to $70 \mathrm{~m}$. Flying fish live in warm waters (more than $26^{\circ} \mathrm{C}$ ) with a salinity more than $30 \mathrm{ppt}$, a pH more than 7.75, and dissolved oxygen (DO) concentrations more than $4.2 \mathrm{~mL} \mathrm{~L}^{-1}$. One of the declines in the catch is due to an indication of the effect of decreasing the abundance of small pelagic fish due to excessive fishing activities (Atmaja, 2007; Suwarno, 2013).

\section{Conclusion}

Catch-catching efforts (CPUE) tended to increase from 2015 to 2019 with an average by $7327.5 \mathrm{~kg}$. The highest CPUE of flying fish occurred in 2019 by $13365.7 \mathrm{~kg} \mathrm{trip}^{-1}$, the lowest CPUE occurred in 2016 by $1050.6 \mathrm{~kg} \mathrm{trip}^{-1}$. The peak season for catching floating fishes occurred in December. Furthermore, the fishing should be conducted in May-December, and the catching famine season occured in January, bad fishing was in January-April.

\section{References}

Almuas. 2005. Analysis of characteristic of oseaonographic parameters for determination of pelagic potential fishing areas in the south China sea waters in the east season. Thesis. Postgraduate of Bogor Agricultural Institute.

Avrionesti, Putri MR. 2018. Identification of Decapterus potential fishing grounds in Java and western Kalimantan seas. IOP Conference Series: Eart and Environmental Science. 162(1): 12-22.

Astuti EM. 2008. Dimensions of shrimp trawl unit unit and level of shrimp resource utilization in Arafura sea water. Thesis. Division of Fisheries Resource Utilization, Faculty of Fisheries and Marine Sciences. IPB. Bogor.

Atmaja SB, Nugroho D. 2007. Overfishing in semi-ring trawl fisheries in the Lawa Sea and its Management Implications. Indonesian Fisheries Policy Journal. 3(1): 51-60.

Aziz KA, Widodo J, Boer M, Djamali A, Ghofar A. 2000. Reevaluation of Fish Resources Potential Up Dating Potential Economical Fish Resources Potential (Final Report). Center for Coastal and Ocean Resource Study, IPB, Bogor.

DPKB (Department of Maritime Affairs and Fisheries Banyuwangi Regency). 2010. Annual report of the department of maritime affairs and fisheries of banyuwangi regency. Banyuwangi: DKP Banyuwangi.

Directorate General of Fisheries. 1998. Handbook for introduction to marine fisheries sources part i (types of important economic fish). Jakarta: Directorate General of Fisheries of the Ministry of Agriculture.

Genisa A. S. 1998. Some notes on the biology of flying fish of the genus Decapterus sp. Oceana. 2 (2): 27-36.

Gulland JA. 1983. Fish Stock Assessment. A Manual of Basic Methods. Chichester: John Wiley and Sons, FAO / Wiley series on food and agriculture, 1. 223 pp. 
Imron M, Nurkayah R, Purwangka F. 2017. Fishermen knowledge and skills about work safety at PPP Muncar, Banyuwangi. Albacore. 1 (1): 99-109.

Inoue M. 1961. A study of fishing power of the purse seine fisheries. Journal of the Tokyo University of Fisheries. 47(2): 123-247.

Mahmud A, Rita L, Bubun. 2015. Sustainable potential of flying fish (Decapterus spp) based on the trawl catches in the waters of east Southeast Sulawesi. Journal of Agricultural and Fisheries Technology. 6(2): 22-30.

Nontji A. 2002. Laut Nusantara. Jakarta: Djambat

Perdana WT, Solihin L, Purbayanto A. 2012. Lemuria fisheries productivity at Muncar beach fishing port, Banyuwangi, East Java. Essay. Bogor: Faculty of Fisheries and Marine Sciences, Bogor Agricultural University.

Prihartini A, Anggoro S, Asriyanto. 2007. Analysis of the biological appearance of the flying fish (Decapterus sp) captured by purse seine landed in PPN Pekalongan. Jurnal Pasir Laut. 3(1): 61-75.

Sangaji MB, Tangke U, Namsa D. 2016. Potential and level of utilization of flying fish (Decapterus $\mathrm{sp})$ in Ternate Island waters. Agribusiness and Fisheries Scientific Journal, 9(2): 1-10.

Suwarno, Zamroni A. 2013. Distribution of flying fish units (Decapterus Sp) and risk of management of small pelagic fish in the Java Sea. Journal of Indonesian Fisheries Policy. 5(1): 17-24.

Widjojo S. 1966. Payang fisheries in Jakarta Bay around the Thousand Islands. Lap. Major Practice. Fac. IPB Fisheries. Bogor.

Wijaya H. 2002. Pendataan hasil tangkapan ikan di pangkalan pendaratan ikan Muncar kabupaten Banyuwangi. Thesis. Bogor: Faculty of Fisheries and Marine Sciences, Bogor Agricultural University.

Wijayanto D, Fitri ADP. 2016. Productivity analysis of garden purse seine and sleek purse seine with Fishing Base in the Coast Fishery Port (PPP) Muncar, Banyuwangi Regency, East Java. Journal of Fisheries Resources Utilization Management and Technology, 5(1): 102-110. 